Article

\title{
Potentialities of a Membrane Reactor with Laccase Grafted Membranes for the Enzymatic Degradation of Phenolic Compounds in Water
}

\author{
Vorleak Chea, Delphine Paolucci-Jeanjean, José Sanchez and Marie-Pierre Belleville * \\ Institut Européen des Membranes (IEM), ENSCM, UM2, CNRS, Université de Montpellier 2, CC 047, \\ Place Eugène Bataillon 34095, France; E-Mails: vorleak.chea@gmail.com (V.C.); \\ delphine.paolucci@iemm.univ-montp2.fr (D.P.-J.); jose.sanchez@iemm.univ-montp2.fr (J.S.) \\ * Author to whom correspondence should be addressed; \\ E-Mail: marie-pierre.belleville@iemm.univ-montp2.fr; Tel.: +33-467-149-148; Fax: +33-467-149-119.
}

External Editor: Simon Judd

Received: 27 June 2014; in revised form: 8 September 2014 / Accepted: 18 September 2014 /

Published: 6 October 2014

\begin{abstract}
This paper describes the degradation of phenolic compounds by laccases from Trametes versicolor in an enzymatic membrane reactor (EMR). The enzymatic membranes were prepared by grafting laccase on a gelatine layer previously deposited onto $\alpha$-alumina tubular membranes. The 2,6-dimethoxyphenol (DMP) was selected from among the three different phenolic compounds tested (guaiacol, 4-chlorophenol and DMP) to study the performance of the EMR in dead end configuration. At the lowest feed substrate concentration tested $\left(100 \mathrm{mg} \cdot \mathrm{L}^{-1}\right)$, consumption increased with flux (up to $7.9 \times 10^{3} \mathrm{mg} \cdot \mathrm{h}^{-1} \cdot \mathrm{m}^{-2}$ at $\left.128 \mathrm{~L} \cdot \mathrm{h}^{-1} \cdot \mathrm{m}^{-2}\right)$, whereas at the highest substrate concentration $\left(500 \mathrm{mg} \cdot \mathrm{L}^{-1}\right)$, it was shown that the reaction was limited by the oxygen content.
\end{abstract}

Keywords: enzymatic membrane reactor; laccase; phenolic compounds; wastewater treatment

\section{Introduction}

Due to the high toxicity of phenolic compounds for living organisms, their removal from industrial or domestic wastewaters is a current and very important issue. Among the different available technologies for wastewater treatment, the enzymatic conversion of phenols into quinones using laccases 
EC 1.10.3.2 (benzenediol:oxygen oxidoreductases) can be revealed as an attractive alternative [1-5]. These enzymes are multi-copper proteins, which are capable of oxidizing a variety of phenolic and non-phenolic compounds requiring only the presence of oxygen [6]. Laccases catalyze one-electron oxidations by transferring electrons from four substrate molecules to one molecule of molecular oxygen, which is reduced to water [7]. Reaction products-phenoxy radicals-undergo further radical reactions generating various oligomers and polymers, which can be easily eliminated from effluents by sedimentation or filtration.

The coupling of membrane technology and enzymatic reactions in an enzymatic membrane reactor (EMR) results on a process intensification allowing the filtration of charged solutions like wastewaters, simultaneously, with an enzymatic conversion. Two types of EMRs are described in the literature: enzymes may be either circulated freely on the retentate side or immobilized on the membrane surface or inside its porous structure [8]. In the first configuration, the reaction takes place in solution and the membrane allows recycling the biocatalyst, whereas, in the second configuration, the reaction takes place during the transfer through the membrane, allowing high conversion rates because the contact between the substrate and the biocatalyst is enhanced. Both EMR types have been already used for the removal of phenolic compounds from wastewaters [9-15].

In this work, we chose to study the second type of EMR with immobilized laccase because it has been reported that the immobilized form of this enzyme is much more stable than the free form [16-18]. Concerning the fouling phenomena, we took in consideration the assumption that oxidation products (polymers) will be formed after the transmembrane transfer. Active membranes were elaborated by covalent immobilization of laccase from Trametes versicolor onto $\alpha$-alumina membranes with $0.2 \mu \mathrm{m}$, $0.8 \mu \mathrm{m}$, and $1.4 \mu \mathrm{m}$ of mean pore diameter. The choice of an inorganic porous support allows a complete active layer removal thanks to a classical cleaning procedure when the biocatalyst becomes inactive, permitting to use again the support for fresh enzymes grafting $[19,20]$. The main objective of this work is to study and to describe the potentiality of this active grafted membrane towards phenolic compounds degradation.

The efficiency of this enzymatic membrane towards three different model phenolic compounds (4-chlorophenol, guaiacol and 2,6-dimethoxyphenol (DMP)) was evaluated. These compounds were chosen since they may be present in some wastewaters. Guaiacol and DMP are representatives of lignin and humic acid degradation products [21] and chlorophenol is widely used as a fungicide or bactericide; it is also a breakdown product of a wide variety of pesticides.

The enzymatic reactions were first carried out in an EMR in a batch configuration (i.e., tangential filtration mode with both retentate and permeate recycling). In a second step, DMP degradations were carried out using a continuous dead-end filtration configuration and the study was particularly focused on the effects of substrate feed flux and substrate concentration on the reaction conversion.

\section{Experimental Section}

\subsection{Enzyme and Chemicals}

A commercial laccase powder from Trametes versicolor (53739-1G-F; Sigma-Aldrich, St Quentin Fallavier, France) was used as bio-catalyst; it was stored at $-20{ }^{\circ} \mathrm{C}$ until required for used. Substrate 
solutions were prepared from: 2,2-azino-bis(3-ethylbenzothiazoline-6-sulfonic acid) (ABTS) (11557; Fluka, St Quentin Fallavier, France), 4-chlorophenol (185787-100G; Sigma-Aldrich), guaiacol (50880-100G; Fluka) and DMP (38772-25G; Fluka) in $50 \mathrm{mM}$ citrate-phosphate buffer $0.1 \mathrm{mM}$ of $\mathrm{CuSO}_{4}, \mathrm{pH}$ 4. The gelatine (24,360,290; Prolabo, Labover, Montpellier, France), glutaraldehyde (G6257; Sigma-Aldrich) and enzyme solutions were prepared in $50 \mathrm{mM}$ phosphate buffer at $\mathrm{pH} 7$ and $20{ }^{\circ} \mathrm{C}$.

\subsection{Preparation of the Active Membranes}

The active membranes were prepared according to a three-step procedure described in a previous paper [14]. Firstly, ceramic supports ( $\alpha$-alumina tubular membranes from Pall-Exekia, France-length: $15 \mathrm{~cm}$, external diameter: $1 \mathrm{~cm}$, internal diameter: $0.7 \mathrm{~cm}$, effective area: $28.610^{-4} \mathrm{~m}^{2}$ and mean pore size: $0.2 \mu \mathrm{m}, 0.8 \mu \mathrm{m}$ or $1.4 \mu \mathrm{m}$ ) were coated with a gelatine layer by filtration of a $10 \mathrm{~g} \cdot \mathrm{L}^{-1}$ aqueous gelatine solution (transmembrane pressure $\Delta \mathrm{P}=200 \mathrm{kPa}$ and tangential velocity $\mathrm{u}=2 \mathrm{~m} \cdot \mathrm{s}^{-1}$ at $20{ }^{\circ} \mathrm{C}$ ) for $30 \mathrm{~min}$. The thin polymer layer obtained was activated by filling the membranes with a glutaraldehyde solution $\left(4 \%(\mathrm{w} / \mathrm{v})\right.$ for $1 \mathrm{~h}$ at room temperature. Finally, a laccase solution $\left(10 \mathrm{~g} \cdot \mathrm{L}^{-1} \mathrm{of}\right.$ commercial powder in $50 \mathrm{mM}$ phosphate buffer, $\mathrm{pH}$ 7) was allowed to react with the free aldhehyde groups of the glutaraldehyde for $2 \mathrm{~h}$ at room temperature. After each step, the excess solution was removed by washing the membranes four times with the same phosphate buffer. The enzymatic membranes were then dried in a desiccator under $\mathrm{P}_{2} \mathrm{O}_{5}$ and stored in a desiccator under silica gel until required for use. For blank experiments, non-active membranes were prepared using a similar procedure, but the enzyme solution was replaced by a buffer solution without enzyme.

After use, the ceramic supports were soaked in a sodium hypochlorite solution $(5 \%(\mathrm{v} / \mathrm{v}))$ prepared with warm water $\left(40{ }^{\circ} \mathrm{C}\right)$ for $15 \mathrm{~min}$. The membranes were then rinsed and washed, following a standard regeneration sequence that involves successive basic and acidic washings, as recommended by the supplier. The ceramic supports were not re-used until the initial water flux was recovered.

\subsection{Enzymatic Membrane Reactor (EMR)}

The pilot and the EMR used for phenols degradation are presented in Figure 1. The reactor can be used in two distinct configurations: dead-end and tangential, by respective closing or opening of valve $\mathrm{V}_{1}$. A controlled temperature chamber was used to maintain the EMR at $40{ }^{\circ} \mathrm{C}$. In dead-end configuration, the substrate concentration of the feed solution remains constant throughout the experiment, whereas, in batch tangential configuration (i.e., both retentate and permeate are recycled in the feed tank), the system works in non-steady state conditions while substrate concentration decreases continuously with time. If required, permeate can be recycled into the feed tank through valve $\mathrm{V}_{2}$. In the continuous experiments carried out over a long period (in dead-end configuration mode without recycling of the permeate stream), fresh substrate was continuously added to the feed tank. Continuous flow of air $\left(5 \mathrm{~L} \cdot \mathrm{h}^{-1}\right)$ was bubbled through the feed solution maintaining the reaction medium under oxygen saturation as verified by an oxygen sensor (inoLab ${ }^{\circledR}$ Oxi 730, supplier SODIPRO, Echirolles, France) and the contents were mixed perfectly using a magnetic stirrer. A cooling system comprising a condenser programmed at $5{ }^{\circ} \mathrm{C}$ was placed over the air exit to avoid water evaporation and phenolic compound loss. 
Figure 1. Pilot unit. 1: membrane module; 2: feed tank; 3: fresh substrate feed; 4: air bubbling feed; 5: substrate feed; 6: permeate exit; 7: retentate; 8: pump; 9: pressure transducer; 10: cooling system; 11: temperature controlled chamber; $\mathbf{V}_{\mathbf{1}}$ and $\mathbf{V}_{\mathbf{2}}$ : valves.

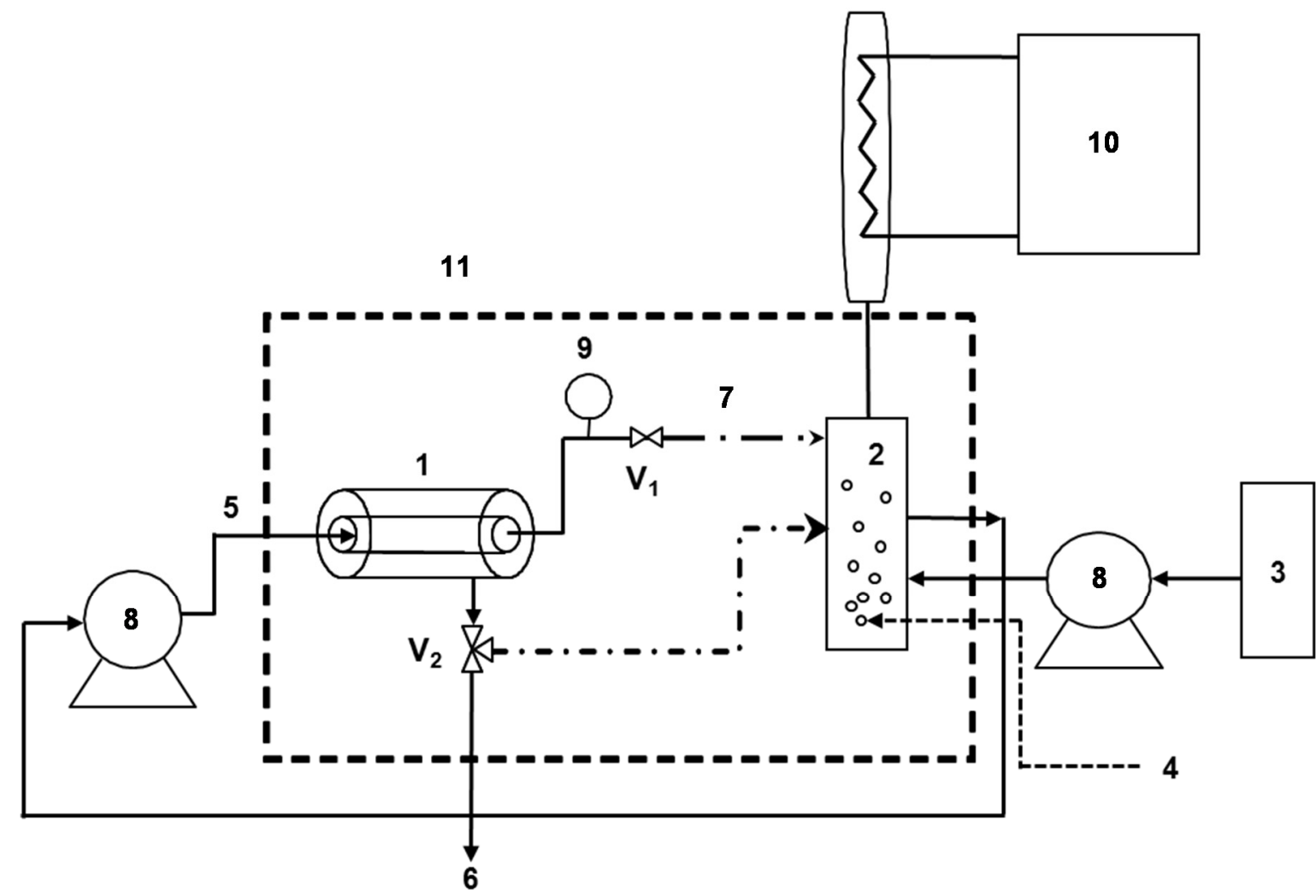

\subsection{Phenolic Compounds Degradation in the EMR}

Before use, each enzymatic membrane was placed in the EMR and hydrated with $50 \mathrm{mM}$ citrate-phosphate buffer containing $0.1 \mathrm{mM}$ of $\mathrm{CuSO}_{4}$ at $\mathrm{pH}$. The effect of the type of substrate was studied in batch configuration with the EMR being operated in tangential filtration mode with a transmembrane pressure of $200 \mathrm{kPa}$ and a tangential velocity of $0.16 \mathrm{~m} \cdot \mathrm{s}^{-1}$. The reactor was filled with a solution of one of the three phenolic compounds prepared at $100 \mathrm{mg} \cdot \mathrm{L}^{-1}$ in the same buffer described above. Both the retentate and permeate were recycled into the feed tank. The remaining experiments were carried out exclusively with DMP solutions in continuous dead-end filtration mode (valve $\mathrm{V}_{1}$ closed and permeate being continuously removed). Different concentrations of DMP (from 100 to $500 \mathrm{mg} \cdot \mathrm{L}^{-1}$ prepared in the same citrate-phosphate buffer $\left.\mathrm{pH} 4\right)$ were tested. Feed flow $(\mathrm{F})$ varied from 0.03 to $0.36 \mathrm{~L} \cdot \mathrm{h}^{-1}$, corresponding to 11 to $128 \mathrm{~L} \cdot \mathrm{h}^{-1} \cdot \mathrm{m}^{-2}$. These values were chosen based on the mean pore diameters of the membranes $(0.2 \mu \mathrm{m}, 0.8 \mu \mathrm{m}$ and $1.4 \mu \mathrm{m})$. Depending on the feed flow the transmembrane pressure values varied between $0 \mathrm{kPa}$ and $400 \mathrm{kPa}$. For each experiment, both permeate and feed samples were withdrawn regularly for HPLC analysis. All of the experiments were carried out at $40^{\circ} \mathrm{C}$.

To take into account possible non-enzymatic degradation, blank experiments were also carried out with the membranes being prepared without enzyme for both filtration modes and all tested substrates. 
Substrate conversion for tangential filtration mode was calculated using Equations (1) and substrate conversion and consumption for continuous dead-end filtration mode were calculated using Equations (2) and (3):

$$
\begin{gathered}
\text { Conversion }(\%)=\left(1-\frac{C_{\text {phenol,feed }}}{C_{\text {phenol,feed, initial }}}\right) \times 100 \\
\text { Conversion }(\%)=\left(1-\frac{C_{\text {phenol, permeate }}}{C_{\text {phenol, feed }}}\right) \times 100 \\
\text { Consumption rate }\left(\mathrm{mg} \cdot \mathrm{h}^{-1}\right)=\left(C_{\text {phenol,feed }}-C_{\text {phenol,permeate }}\right) \times F
\end{gathered}
$$

where $\mathrm{F}$ is the feed flow $\left(\mathrm{L} \cdot \mathrm{h}^{-1}\right)$; and $\mathrm{C}_{\text {phenol,feed,initial, }} \mathrm{C}_{\text {phenol,feed }}$ and $\mathrm{C}_{\text {phenol,permeate }}$ are the substrate concentrations $\left(\mathrm{mg} \cdot \mathrm{L}^{-1}\right)$ in feed at time " 0 " and at time " $\mathrm{t}$ " and permeate at time " $t$ ", respectively.

Each run was carried out with a new enzymatic membrane and the results shown below are the mean values of the various experiments.

\subsection{Analysis}

Laccase activity was determined from the change in optical density (at $420 \mathrm{~nm}, \varepsilon 420=36,000 \mathrm{M}^{-1} \cdot \mathrm{cm}^{-1}$ ) of $50 \mathrm{mM}$ citrate-phosphate buffer, $\mathrm{pH} 4$ containing ABTS $(1 \mathrm{mM})$ as substrate [22]. ABTS was chosen since this substrate is more sensitive than phenol based substrate [23]. One unit of laccase activity was defined as the amount of enzyme required to oxidize $1 \mu \mathrm{mol}$ of ABTS per minute.

The immobilization yield was estimated by comparing the activity of the laccase solution before and after the immobilization step, taking into account the activity of washings, as well as that of the permeate recovered at the early stages of the conditioning step (see Section 2.4). The concentration in phenolic compounds of the withdrawn samples were analyzed by HPLC (Waters e2695 Separations Module, Waters ${ }^{\circledR}$, France) using a Symmetry ${ }^{\circledR} \mathrm{C}_{18}$ column. Samples of $20 \mu \mathrm{L}$ were injected and eluted at $1 \mathrm{~mL} \cdot \mathrm{min}^{-1}$ (mobile phase: $50 \mathrm{mM}$ citrate-phosphate buffer, $\mathrm{pH}$ 4/acetonitrile (50/50) in the case of 4-chlorophenol and guaiacol or $50 \mathrm{mM}$ citrate-phosphate buffer, $\mathrm{pH}$ 4/acetonitrile (80/20) for 2,6-dimetnoxyphenol) and $30{ }^{\circ} \mathrm{C}$. Elution profiles were monitored at $296 \mathrm{~nm}$ (Detector UV/VIS (PDA 2996), Waters ${ }^{\circledR}$, St Quentin en Yvelines, France).

\section{Results and Discussion}

\subsection{Degradation of Phenolic Compounds in the EMR}

The catalytic efficiency of an enzymatic process depends to a very large extent on the choice of the reactor, the reaction media, the operating conditions and of course, the reactivity of the enzymes towards the substrates. In the case of laccases, the degree of conversion of phenolic compounds depends on the chemical structure of the compounds. Although, laccases from Trametes versicolor are able to degrade a wide range of simple and complex phenolic compounds [4, 24-25], it is important to characterize the EMR under good measurable operating conditions by selecting a substrate with quantifiable reactivity to laccase action. As explained above, these preliminary experiments were 
carried out in batch tangential configuration (in tangential filtration mode with recycling both the retentate and permeate into the feed tank). The $\mathrm{pH}$ and temperature were fixed to 4 and $40{ }^{\circ} \mathrm{C}$, respectively, these values correspond to the optimal activity towards ABTS. Figure 2 shows the results evolution of the conversion versus time obtained for the three phenolic compounds studied (4-chlorophenol, guaiacol and DMP) during batch experiments carried out with or without enzymes. It is important to notice that the average immobilization yield of laccase obtained for the membranes used in this work was equal to $8.5 \% \pm 1.5 \%$. This yield corresponds to an amount of laccase immobilized on membranes equal to $7.0 \times 10^{4} \pm 5.0 \times 10^{3} \mathrm{U} \cdot \mathrm{m}^{-2}$. This immobilization yield could not be defined in terms of immobilized proteins since the possible release of gelatin during the grafting procedure could lead to an overestimation of the protein concentration resulting on miss estimation of the total laccase grafted.

Figure 2. Conversion of 4-chlorophenol $(\diamond, \bullet)$, guaiacol $(\odot, \bullet), 2,6$-dimetoxyphenol $(\Delta, \mathbf{\Delta})$ degradation in EMR working in batch mode (without enzyme-open symbols-and with enzyme-closed symbols-, $100 \mathrm{mg} \cdot \mathrm{L}^{-1}$ of phenolic substrate in $50 \mathrm{mM}$ citrate-phosphate buffer $\mathrm{pH} 4$ with $0.1 \mathrm{mM}$ of $\mathrm{CuSO}_{4}, \Delta \mathrm{P}=200 \mathrm{kPa}$, tangential velocity $=0.16 \mathrm{~m} \cdot \mathrm{s}^{-1}$, $\mathrm{T}=40{ }^{\circ} \mathrm{C}$, membrane pore diameter $0.2 \mu \mathrm{m}$ ). The error of measurements is $\leq 10 \%$.

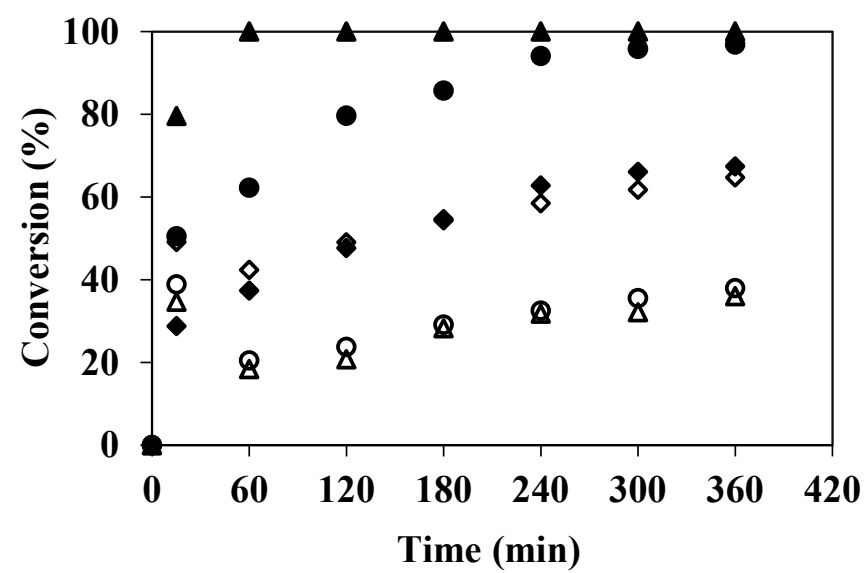

Figure 2 shows that, after $6 \mathrm{~h}$, the conversion observed in blank runs (membranes non-grafted with laccase) was $65 \%$ for 4 -chlorophenol, but it was only $38 \%$ and $36 \%$ for guaiacol and DMP, respectively. A spontaneous partial depletion of phenolic compounds from aqueous solutions was already observed by Ko and Chen [14], Ba et al. [26], Arsuaga et al. [27], Williams et al. [28], and Bódalo et al. [29]. According to these authors, spontaneous depletion might due to one more phenomena related to substrate molecular weight, substrate adsorption, filtration operating conditions, or auto-oxidation. In particular, enzymatic depletion can take place simultaneously with auto oxidation, but generally it is impossible to distinguish the depletion level caused by each one of these reactions. In our case, as both permeate and retentate were recycled in the feed tank, intermediate products could react with the substrate. On the contrary, when enzymatic membranes were used, conversion was complete (100\%) for guaiacol and DMP, whereas no change in conversion was observed for 4-chlorophenol. According to this result, we cannot assert that the laccase is not active towards 4-chlorophenol, but only that the EMR does not enhance the depletion level observed by auto-degradation. Furthermore, it can be noticed that DMP was completely depleted after less than $1 \mathrm{~h}$ of reaction, whereas conversion of 
guaiacol reached $100 \%$ only after $4 \mathrm{~h}$ under the temperature $\left(40{ }^{\circ} \mathrm{C}\right)$ and $\mathrm{pH}(4)$ tested. Nevertheless, it must be taken into account that in batch configuration, permeate and retentate are recycled continuously and, therefore, conversion results from cumulative depletion of the concentration. The results shown in Figure 2 are in good agreement with the conversions reported in some previous works. Indeed, chloro substituents have been reported to be much less reactive to laccases than methoxy substituents [30,31]. Among the monochlorophenols, the 4-chlorophenol is known to be recalcitrant to some laccases [32]. Nevertheless, these results are not exactly in good agreement with the work of Lante et al. [11] who used laccase immobilized onto a spiral-wound asymmetric polyethersulphone and reported that even if the DMP was the most reactive phenol, the 4-chlorophenol was more reactive than guaiacol. Ko and Chen [14] have reported that the oxidation of methoxy- and hydroxy-substituted phenols by laccase was enhanced by the formation of rather stable free radicals. Additional electron-donating methoxy groups in DMP provide more free-radicals containing resonance forms for reaction intermediates. Chivukula et al. have also published that the number of methoxy substituent was very important, lacasse was much more reactive towards the 2,6-dimethoxy-subsituted compounds than to 2-methoxy-substituted compounds [31].

As it has been described above, the study of the effect of process parameters on the degradation rate was carried out exclusively with DMP in continuous dead-end filtration mode. The values of $\mathrm{pH}$ and temperature were the same as previously and corresponded also to the optimal for DMP degradation with the laccase from Trametes versicolor. To take into account the auto-oxidation degree, some experiments were carried out with non-active membranes. In such configuration the DMP auto-degradation was not observed as it was noticed in batch configuration. The feed concentration remained practically constant and equal to the initial concentration throughout the experiment. Hence, it confirms that the non-enzymatic oxidation observed during experiments in batch configuration could be the result of operating conditions (i.e., substrate agitation, shear stress due to tangential velocity, recycling of the oxidation products, etc.). Indeed, DMP consumption was always calculated by comparing DMP concentrations in feed and permeate samples withdrawn at the same time.

\subsection{Feed Flux Effect on DMP Degradation}

When an EMR is used in dead-end filtration mode, the feed or substrate flux and permeate flux are identical. Thus, increasing this parameter results in a decrease in residence time, which may affect reactor efficiency and particularly the conversion. In order to study the effect of feed flux on DMP degradation, experiments were carried out with different feed fluxes and enzymatic membranes prepared with different mean pore diameters of the raw ceramic support $(0.2,0.8$, and $1.4 \mu \mathrm{m})$. All the experiments were carried out for $90 \mathrm{~min}$. Substrate consumption and conversion versus substrate flux results are shown in Figure 3.

When feed flux is lower than $32 \mathrm{~L} \cdot \mathrm{h}^{-1} \cdot \mathrm{m}^{-2}$, substrate consumption is the same for all membranes for a given feed flux, and does not depend on the mean pore size of the membrane support. It was not possible to draw conclusions above $42 \mathrm{~L} \cdot \mathrm{h}^{-1} \cdot \mathrm{m}^{-2}$ as the experiments could not be carried out with the $0.2 \mu \mathrm{m}$ and $0.8 \mu \mathrm{m}$ porous supports because transmembrane pressure increases continuously and reached values higher than $400 \mathrm{kPa}$. Figure 3 also shows that any additional supply of substrate resulting from an increase in feed flux produces consumption enhancement. The substrate consumption 
increases from $2.7 \mathrm{mg} \cdot \mathrm{h}^{-1}$ to $22.2 \mathrm{mg} \cdot \mathrm{h}^{-1}$ with an increase in feed flux from $11 \mathrm{~L} \cdot \mathrm{h}^{-1} \cdot \mathrm{m}^{-2}$ to $128 \mathrm{~L} \cdot \mathrm{h}^{-1} \cdot \mathrm{m}^{-2}$. This result is consistent with those reported by Lante et al. [12] and Erhan et al. [13], and confirms the assumption that the reaction is substrate-limited under the studied conditions. At the highest feed flux $\left(128 \mathrm{~L} \cdot \mathrm{h}^{-1} \cdot \mathrm{m}^{-2}\right), 7.9 \times 10^{3} \mathrm{mg} \cdot \mathrm{h}^{-1} \cdot \mathrm{m}^{-2}$ DMP were depleted from a feed solution containing $100 \mathrm{mg} \cdot \mathrm{L}^{-1}$ of DMP. It should be noted that this DMP consumption rate does not seem to be the optimum since, according to the figure trend, higher values of DMP consumption can be expected at higher feed fluxes. Although it is not always easy or reasonable to compare the performances of various EMRs, enzymes and/or substrates can be different, it should be noted that the value reached is similar to/or higher than the consumption reported in the literature for the degradation of other phenolic compounds in EMRs. Erhan et al. [13] reported for a feed of $9 \times 10^{-4} \mathrm{~mL} \cdot \mathrm{cm}^{-2} \cdot \mathrm{s}^{-1}$ (i.e., $32.4 \mathrm{~L} \cdot \mathrm{h}^{-1} \cdot \mathrm{m}^{-2}$ ) of $467 \mathrm{mg} \cdot \mathrm{L}^{-1}$ of a catechol solution a degradation rate of $0.153 \mu \mathrm{g} \cdot \mathrm{s}^{-1} \cdot \mathrm{cm}^{-2}$ (i.e., $5.5 \times 10^{3} \mathrm{mg} \cdot \mathrm{h}^{-1} \cdot \mathrm{m}^{-2}$. From the values reported by Lante et al. [11], it is possible to estimate the DMP degradation capacity of their EMR at $60 \mathrm{mg} \cdot \mathrm{h}^{-1} \cdot \mathrm{m}^{-2}$. Despite of a relatively high membrane surface area $\left(0.14 \mathrm{~m}^{2}\right)$, their DMP removal efficiency was only equal to $69 \%$ when the reactor was fed at $2 \mathrm{~mL} \cdot \mathrm{min}^{-1}$ (i.e., $0.86 \mathrm{~L} \cdot \mathrm{h}^{-1} \cdot \mathrm{m}^{-2}$ ) with $100 \mathrm{mg} \cdot \mathrm{L}^{-1}$ of substrate solution.

Figure 3. Feed flux effect on DMP conversion (closed symbols) and substrate consumption (open symbols) in an EMR used in a continuous dead-end filtration configuration $\left(100 \mathrm{mg} \cdot \mathrm{L}^{-1} \mathrm{DMP}\right.$ in $50 \mathrm{mM}$ citrate-phosphate buffer $\mathrm{pH} 4$ with $0.1 \mathrm{mM} \mathrm{CuSO}, \mathrm{T}=40{ }^{\circ} \mathrm{C}$, membrane pore diameter: $0.2 \mu \mathrm{m}((\diamond, \diamond), 0.8 \mu \mathrm{m}(\circ, \bullet)$, and $1.4 \mu \mathrm{m}(\Delta, \boldsymbol{\Delta})$.

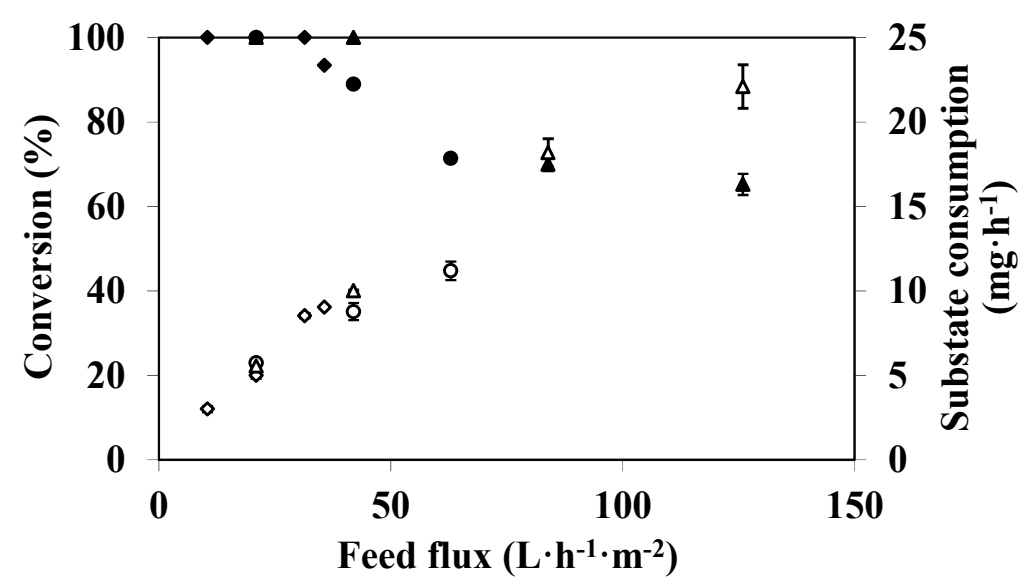

Finally conversion was affected when feed flux was increased but it can be maintained at $100 \%$ as long as the feed flux is kept below $32 \mathrm{~L} \cdot \mathrm{h}^{-1} \cdot \mathrm{m}^{-2}$. An increase in feed flux leads to rapid conversion decrease because we decrease simultaneously the contact time, for example, for fluxes of $64 \mathrm{~L} \cdot \mathrm{h}^{-1} \cdot \mathrm{m}^{-2}$ and $128 \mathrm{~L} \cdot \mathrm{h}^{-1} \cdot \mathrm{m}^{-2}$, conversion reaches only $75 \%$ and $65 \%$, respectively. Consequently, if total phenolic compound degradation is required, the feed flux should not exceed $32 \mathrm{~L} \cdot \mathrm{h}^{-1} \cdot \mathrm{m}^{-2}$. Increasing of feed flux reducing the conversion was already observed by Lante et al. [11] and Lloret et al. [33] when they studied, respectively, the degradation of phenolic compounds by laccase immobilized onto a spiral-wound asymmetric polyethersulphone membrane and by laccase immobilized in a microreactor.

Alternatively, it is also possible to maintain a high consumption rate with a good conversion by using a multi-step process involving EMRs with different active surfaces, placed in series, for example, a first series of EMRs can be fed at high feed flux, which ensures high phenolic compound 
consumption, while a second series is fed with the permeate of the first EMRs at a lower feed flux, allowing a complete degradation of the phenolic compounds.

\subsection{Effect of Substrate Concentration on DMP Degradation}

According to the above results, the efficiency of the EMR was limited by a lack of substrate when it was fed with a $100 \mathrm{mg} \cdot \mathrm{L}^{-1}$ of DMP solution, irrespective of the feed flux used. In order to overcome this limitation, experiments were carried out with an enzymatic membrane prepared with a $0.2 \mu \mathrm{m}$ porous support and with substrate solutions prepared at different concentrations $(100,250$, and $\left.500 \mathrm{mg} \cdot \mathrm{L}^{-1}\right)$. The feed flux was kept constant at $11 \mathrm{~L} \cdot \mathrm{h}^{-1} \cdot \mathrm{m}^{-2}$ throughout a 90 min operating time. The conversion and the substrate consumption values versus substrate concentration are shown in Figure 4.

Figure 4. Substrate concentration effect on DMP degradation in an EMR used in a continuous dead-end filtration configuration $\left(100,250\right.$, and $500 \mathrm{mg} \cdot \mathrm{L}^{-1} \mathrm{DMP}$ in $50 \mathrm{mM}$ citrate-phosphate buffer pH 4 with $0.1 \mathrm{mM} \mathrm{CuSO}_{4}$, feed flux $11 \mathrm{~L} \cdot \mathrm{h}^{-1} \cdot \mathrm{m}^{-2}, \mathrm{~T}=40{ }^{\circ} \mathrm{C}$, membrane pore diameter: $0.2 \mu \mathrm{m}$ ) (substrate consumption $(\diamond)$; conversion $(\mathbf{a})$.

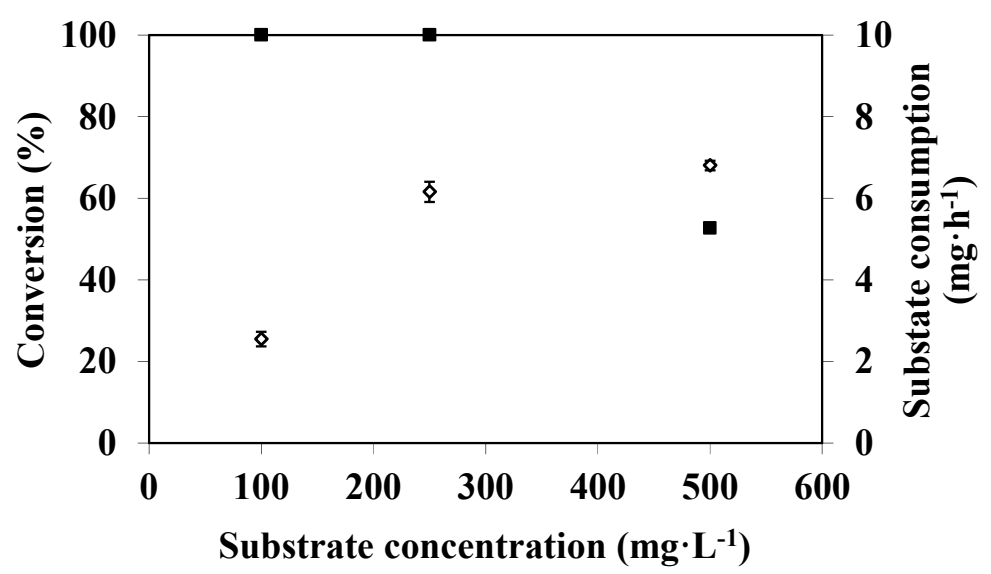

Firstly it can be seen that conversion remains constant and equal to $100 \%$ as long as the substrate concentration is less than or equal to $250 \mathrm{mg} \cdot \mathrm{L}^{-1}$ and then it drops to $46 \%$ when substrate concentration increases up to $500 \mathrm{mg} \cdot \mathrm{L}^{-1}$. In the latter case, a large amount of substrate was transferred across the membrane before being transformed. Nevertheless, substrate consumption is enhanced from $2.4 \mathrm{mg} \cdot \mathrm{h}^{-1}$ to $6.2 \mathrm{mg} \cdot \mathrm{h}^{-1}$ when the concentration is increased from 100 to $250 \mathrm{mg} \cdot \mathrm{L}^{-1}$; it then tends to level off, increasing very slightly to $6.9 \mathrm{mg} \cdot \mathrm{h}^{-1}$ when the substrate concentration reaches $500 \mathrm{mg} \cdot \mathrm{L}^{-1}$. Katuri et al. [34] also showed that the phenolic compounds were completely degraded by laccase until a concentration of $20 \mathrm{mg} \cdot \mathrm{L}^{-1}$ whereas at higher concentrations the conversion decreased.

If we compare these last results with those obtained at different feed fluxes but with a constant substrate concentration (i.e., $100 \mathrm{mg} \cdot \mathrm{L}^{-1}$ ) (see Figure 5). We can notice that increasing the mass flux of the substrate by either increasing feed flux or substrate concentration results on different substrate consumption. In the first case, consumption increases continuously and the maximum consumption rate observed is equal to $9.5 \mathrm{mg} \cdot \mathrm{h}^{-1}$ for a substrate mass flux of $10.5 \mathrm{mg} \cdot \mathrm{h}^{-1}$ (i.e., when the reactor was fed at $36.5 \mathrm{~L} \cdot \mathrm{h}^{-1} \cdot \mathrm{m}^{-2}$ with a $100 \mathrm{mg} \cdot \mathrm{L}^{-1}$ of DMP solution). In the second case, the consumption levels off and the maximum consumption rate is only $6.9 \mathrm{mg} \cdot \mathrm{h}^{-1}$ for a substrate mass flux of $15.7 \mathrm{mg} \cdot \mathrm{h}^{-1}$ 
(i.e., when the reactor was fed at $11 \mathrm{~L} \cdot \mathrm{h}^{-1} \cdot \mathrm{m}^{-2}$ with a $500 \mathrm{mg} \cdot \mathrm{L}^{-1}$ of DMP solution). In this last case, the real substrate concentration near the catalytic site would be certainly important, whereas it would tend to zero in the first set of experiments. Indeed according to Figure 3, the conversion rates obtained with $0.2 \mu \mathrm{m}$ membrane are always equal or close to $100 \%$, whereas this parameter decreases until $50 \%$ when the reactor was fed at low feed flow with high substrate concentration. In the first case, the reaction is, thus, limited by a lack of DMP whereas, in the second case, when DMP concentration is higher than $250 \mathrm{mg} \cdot \mathrm{L}^{-1}$ (i.e., $1.6 \times 10^{-3} \mathrm{M}$ ) and then the reaction may be limited either by the substrate inhibition or by a lack of $\mathrm{O}_{2}$.

Figure 5. Substrate mass flux effect on DMP degradation in an EMR used in a continuous dead-end filtration configuration (DMP in $50 \mathrm{mM}$ citrate-phosphate buffer $\mathrm{pH} 4$ with $0.1 \mathrm{mM} \mathrm{CuSO} 4, \mathrm{~T}=40{ }^{\circ} \mathrm{C}$, membrane pore diameter: $0.2 \mu \mathrm{m}$ ) (reactor fed with 100 $\mathrm{mg} \cdot \mathrm{L}^{-1} \mathrm{DMP}$ at flow rate increased $(\diamond)$; reactor fed at flow rate constant $11 \mathrm{~L} \cdot \mathrm{h}^{-1} \cdot \mathrm{m}^{-2}$ with 100,250 and $\left.500 \mathrm{mg} \cdot \mathrm{L}^{-1} \mathrm{DMP}(\mathbf{\square})\right)$.

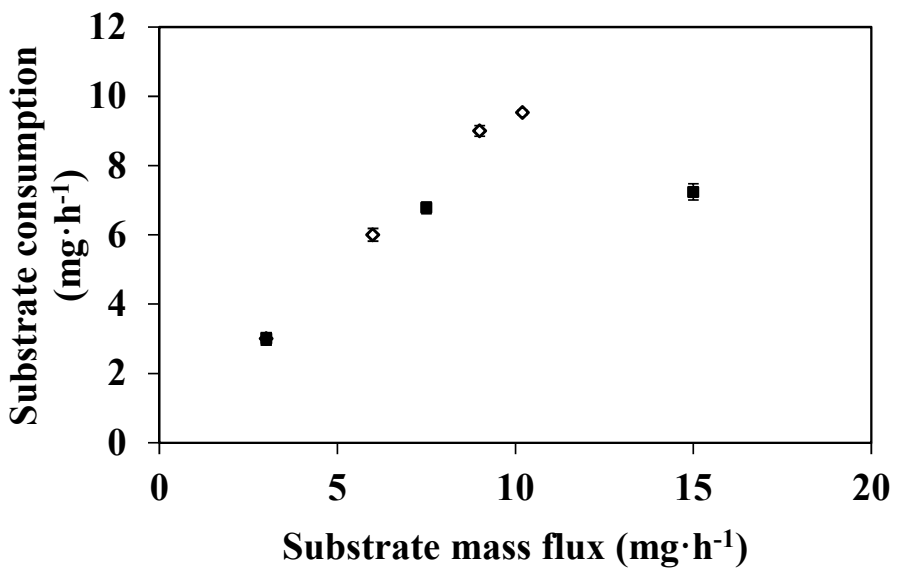

It is well known that high substrate concentrations which normally increase the velocity of enzyme reactions can cause inhibition in about $20 \%$ of all known enzymes. However, to our knowledge this phenomenon has not been reported for the couple laccase-DMP. Nevertheless, laccases activity has been reported to be strongly dependent on oxygen concentration. According to Riva [35], laccase theoretically catalyze the conversion of four molecules of phenolic compounds, together with the reduction of one molecule of oxygen to two molecules of water. However, Kurniawati and Nicell [36] reported that the molar ratio between phenol transformed and oxygen consumed in the catalytic reaction is not constant and varies from 1 to 4 when the phenol concentration increases in the reaction mixture. At high DMP concentration (i.e., $1.6 \times 10^{-3} \mathrm{M}$ or $246 \mathrm{mg} \cdot \mathrm{L}^{-1}$ ), if the stoichiometric ratio is assumed to be equal to 4 , the $\mathrm{O}_{2}$ concentration should be at least $4 \times 10^{-4} \mathrm{M}$. However, even if the air flow was kept constant for all our experiments $\left(\right.$ i.e., $5 \mathrm{~L} \cdot \mathrm{h}^{-1}$ ), which allowed the reaction mixture to remain statured as verified by controls, at $40{ }^{\circ} \mathrm{C}$ the oxygen concentration was $6.4 \mathrm{mg} \cdot \mathrm{L}^{-1}$ or $2 \times 10^{-4} \mathrm{M}$ of $\mathrm{O}_{2}$. This value is much lower than required, thus, the reaction was probably limited by the lack of $\mathrm{O}_{2}$.

In view to confirm this hypothesis, we decided to increase the $\mathrm{O}_{2}$ concentration of the feed solution. For this purpose, the total pressure in the feed tank was increased from 100 to $250 \mathrm{kPa}$ while the temperature was kept constant and equal to $20^{\circ} \mathrm{C}$. In such conditions the $\mathrm{O}_{2}$ concentration measured was then increased from $8.5 \mathrm{mg} \cdot \mathrm{L}^{-1}$ to $21 \mathrm{mg} \cdot \mathrm{L}^{-1}$. The degradation rates observed were equal to 
$7.3 \pm 0.7 \mathrm{mg} \cdot \mathrm{h}^{-1}$ and $14.5 \pm 2.3 \mathrm{mg} \cdot \mathrm{h}^{-1}$ for experiments carried out at 100 and $250 \mathrm{kPa}$, respectively, all the other operating conditions being kept similar. These results confirm that an increase in oxygen content leads to an increase of reaction rate.

\section{Conclusions}

Enzymatic membranes were successfully prepared by covalent bonding of Trametes versicolor laccases onto an $\alpha$-alumina tubular porous support previously coated with a protein. Among the three phenolic compounds tested, 2,6-dimethoxyphenol (DMP) resulted to be the most reactive substrate for the laccase grafted membranes tested in an enzymatic membrane reactor (EMR) operating in tangential filtration configuration. For EMR operating in dead-end filtration configuration, we found that DMP depletion increased continuously with the feed flux. A substrate depletion of $7.9 \times 10^{3} \mathrm{mg} \cdot \mathrm{h}^{-1} \cdot \mathrm{m}^{-2}$ were observed when the reactor was fed continuously with a $100 \mathrm{mg} \cdot \mathrm{L}^{-1}$ of DMP solution at $128 \mathrm{~L} \cdot \mathrm{h}^{-1} \cdot \mathrm{m}^{-2}$. These first results present attractive perspectives for the treatment of industrial phenolic wastewaters. However, investigations are required in order to improve the process.

At high DMP concentrations (over $250 \mathrm{mg} \cdot \mathrm{L}^{-1}$ ), the degradation seems to be limited by the lack of oxygen. Furthermore, if substrate flow-rate is too high, substrate conversion will not be complete and some phenolic compound can remain in the permeate stream. However, in such cases, a bundle of membranes with an in series/parallel configuration with aeration steps can be designed in order to reach a complete conversion of the effluent while obtaining a filtrated water depleted from the phenolic compounds. The degradation of phenolic compounds in wastewaters needs the determination of substrates-enzyme affinity and the process has to be optimized for each type of substrate. Nevertheless, the direct application of this process to domestic wastewaters should not be considered because the organic matrix of such effluents can contain different types of organic molecules able to react with laccases. This process seems to be more indicated for the treatment of charged phenolic industrial wastewaters.

A work at very low concentrations (less than $1 \mathrm{ppm}$ ) and with real wastewaters is under way in order to examine the feasibility of this enzymatic technology under real environmental conditions.

\section{Author Contributions}

Experimental work was carried out by Vorleak Chea while others authors were responsible for designing of the experiments. All authors contributed to the interpretation and discussions, MariePierre Belleville prepared the first version of the manuscript, which was extensively corrected and edited by Marie-Pierre Belleville and José Sanchez.

\section{Conflicts of Interest}

The authors declare no conflict of interest. 


\section{References}

1. Busca, G.; Berardinelli, S.; Resini, C.; Arrighi, L. Technologies for the removal of phenol from fluid streams: A short review of recent developments. J. Hazard. Mater. 2008, 160, 265-288.

2. Durán, N.; Rosa, M.A.; D’Annibale, A.; Gianfreda, L. Applications of laccases and tyrosinases (phenoloxidases) immobilized on different supports: A review. Enzyme Microb. Technol. 2002, 31, 907-931.

3. Aktas, N.; Tanyolac, A. Reaction conditions for laccase catalyzed polymerization of catechol. Bioresour. Technol. 2003, 87, 209-214.

4. Canfora, L.; Iamarino, G.; Rao, M.A.; Gianfreda, L. Oxidative transformation of natural and synthetic phenolic mixtures by Trametes versicolor laccase. J. Agric. Food Chem. 2008, 56, 1398-1407.

5. Kurniawati, S.; Nicell, J.A. Characterization of Trametes versicolor laccase for the transformation of aqueous phenol. Bioresour. Technol. 2008, 99, 7825-7834.

6. Cañas, A.I.; Camarero, S. Laccases and their natural mediators: Biotechnological tools for sustainable eco-friendly processes. Biotechnol. Adv. 2010, 28, 694-705.

7. Demarche, P.; Junghanns, C.; Nair, R.R.; Agathos, S.N. Harnessing the power of enzymes for environmental stewardship. Biotechnol. Adv. 2012, 30, 933-953.

8. Belleville, M.-P.; Paolucci, D.; Rios, G.M. Membrane Bioreactors and the Production of Food Ingredients in Separation, Extraction and Concentration Processes in the Food Beverage and Nutraceutical Industries; SSH Rizvi, Ed.; Woodhead Publishing Limited: Cambridge, UK, 2010; pp. 314-337.

9. Edwards, W.; Bownes, R.; Leukes, W.D.; Jacobs, E.P.; Sanderson, R.; Rose, P.D.; Burton, S.G. A capillary membrane bioreactor using immobilized polyphenol oxidase for the removal of phenols from industrial effluents. Enzyme Microb. Technol. 1999, 24, 209-217.

10. Edwards, W.; Leukes, W.D.; Rose, P.D.; Burton, S.G. Immobilization of polyphenol oxidase on chitosan-coated polysulphone capillary membranes for improved phenolic effluent bioremediation. Enzyme Microb. Technol. 1999, 25, 769-773.

11. Lante, A.; Crapisi, A.; Krastanov, A; Spettoli, P. Biodegradation of phenols by laccase immobilized in a membrane reactor. Process Biochem. 2000, 36, 51-58.

12. Jolivalt, C.; Brenon, S.; Caminade, E.; Mougin, C.; Pontié, M. Immobilization of laccase from Trametes versicolor on a modified PVDF microfiltration membrane: Characterization of the grafted support and application in removing a phenylurea pesticide in wastewater. J. Membr. Sci. 2000, 180, 103-113.

13. Erhan, E.; Keskinler, B.; Akay, G.; Algur, O.F. Removal of phenol from water by membrane-immobilized enzymes Part I. Dead-end filtration. J. Membr. Sci. 2002, 206, 361-373.

14. Ko, C.-H.; Chen, S.-S. Enhanced removal of three phenols by laccase polymerization with MF/UF membranes. Bioresour. Technol. 2008, 99, 2293-2298.

15. Calabro, V.; Curcio, S.; De Paola, M.G.; Lorio, G. Optimization of membrane bioreactor performances during enzymatic oxidation of waste bio-polyphenols. Desalination 2009, 236, $30-38$. 
16. Palmieri, G.; Giardina, P.; Desiderio, B.; Marzullo, L.; Giamberini, M.; Sannia, G. A new enzyme immobilization procedure using copper alginate gel: Application to a fungal phenol oxidase. Enzyme Microb. Technol. 1994, 16, 151-158.

17. Wu, Y.; Jiang,; Jiao, J.; Liu, M.; Hu, F.; Griffiths, B.S.; Li, H. Adsorption of Trametes versicolor laccase to soil iron and aluminumminerals: Enzyme activity, kinetics and stability studies. Colloid Surface B 2014, 114, 342-348.

18. De Cazes, M.; Belleville, M.-P.; Petit, E.; Llorca, M.; Rodríguez-Mozaz, S.; de Gunzburg, J.; Barceló, D.; Sanchez-Marcano, J. Design and optimization of an enzymatic membrane reactor for the degradation of pharmaceutical micropollutants. Catal. Today 2014, 236, 146-152.

19. Belleville, M.-P.; Lozano, P.; Iborra, J.L.; Rios, G.M. Preparation of hybrid membranes for enzymatic reaction. Sep. Purif. Technol. 2001, 25, 229-233.

20. Gumí, T.; Albacete, J.F.-D.; Paolucci-Jeanjean, D.; Belleville, M.-P.; Rios, G.M. Study of the influence of the hydrodynamic parameters on the performance of an enzymatic membrane reactor. J. Membr. Sci. 2008, 311, 147-152.

21. Voudrias, E.L.; Larson, R.A.; Snoeyink, V.L. Effects of activated carbon on the reactions of free chlorine with phenols. Environ. Sci. Technol. 1985, 19, 441-449.

22. Dodor, D.E.; Hwang, H.-M.; Ekunwe, S.I.N. Oxidation of anthracene and benzo[a]pyrene by immobilized laccase from Trametes versicolor. Enzyme Microb. Technol. 2004, 35, 210-217.

23. Hou, J.; Dong, G.; Ye, Y.; Chen, V. Laccase immobilization on titania nanoparticles and titania-functionalized membranes. J. Membrane Sci. 2014, 452, 229-240.

24. Muktadirul Bari Chowdhury, A.K.M.; Akratos, C.S.; Vayenas, D.V.; Pavlou, S. Olive mill waste composting: A review. Int. Biodeter. Biodegr. 2013, 85, 108-119.

25. Kudanga, T.; Nyanhongo, G.S.; Guebitz, G.M.; Burton, S. Potential applications of laccase-mediated coupling and grafting reactions: A review. Enzyme Microb. Tech. 2011, 48, 195-208.

26. Ba, S; Haroune, L.; Cruz-Morató, C.; Jacquet, C.; Touahar, I.E.; Bellenger, J.-P.; Legault, C.Y.; Jones, J.P.; Cabana, H. Synthesis and characterization of combined cross-linked laccase and tyrosinase aggregates transforming acetaminophen as a model phenolic compound in wastewaters. Sci. Total Environ. 2014, 487, 748-755.

27. Arsuaga, J.M.; López-Muñoz, M.J.; Sotto, A. Correlation between retention and adsorption of phenolic compounds in nanofiltration membranes. Desalination 2010, 250, 829-832.

28. Williams, M.E.; Hestekin, J.A.; Smothers, C.N.; Bhattacharyya, D. Separation of organic pollutants by reverse osmosis and nanofiltration membranes: Mathematical models and experimental verification. Ind. Eng. Chem. Res. 1999, 38, 3683-3695.

29. Bódalo, A.; Gómez, E.; Hidalgo, A.M.; Gómez, M.; Murcia, M.D.; López, I. Nanofiltration membranes to reduce phenol concentration in wastewater. Desalination 2009, 245, 680-686.

30. Shuttleworth, K.L.; Bollag, J.-M. Soluble and immobilized laccase as catalysts for transformation of substituted phenols. Enzyme Microb. Technol. 1986, 8, 171-177.

31. Chivukula, M.; Renganathan, V. Phenolic Azo Dye Oxidation by Laccase from Pyricularia oryzae. Appl. Environ. Microb. 1995, 61, 4374-4377. 
32. Itoh, K.; Fujita, M.; Kumano, K.; Suyama, K.; Yamamoto, H. Phenolic acids affect transformations of chlorophenols by a Coriolus versicolor laccase. Soil Biol. Biochem. 2000, 32, 85-91.

33. Lloret, L.; Eibes, G.; Moreira, M.T.; Feijoo, G.; Lema, J.M.; Miyazaki, M. Improving the catalytic performance of laccase using a novel continuous-flow microreactor. Chem. Eng. J. 2013, 223, 497-506.

34. Katuri, K.P.; Mohan, S.V.; Sridhar, S.; Pati, B.R.; Sarma, P.N. Laccase-membrane reactors for decolorization of an acid azo dye in aqueous phase: Process optimization. Water Res. 2009, 43, 3647-3658.

35. Riva, S. Laccases: Blue enzymes for green chemistry. Trends Biotechnol. 2006, 24, 219-226.

36. Kurniawati, S.; Nicell, J.A. Variable stoichiometry during the laccase-catalysed oxidation of aqueous phenol. Biotechnol. Prog. 2007, 23, 389-397.

(C) 2014 by the authors; licensee MDPI, Basel, Switzerland. This article is an open access article distributed under the terms and conditions of the Creative Commons Attribution license (http://creativecommons.org/licenses/by/4.0/). 